\title{
ZAMÉ O LA UTOPÍA
}

\author{
ZAMÉ OR THE UTOPIA \\ Enrique Flores*
}

DOI: http://dx.doi.org/10.29043/liminar.v19i2.840

\begin{abstract}
Resumen: Este trabajo forma parte de una investigación más amplia sobre la Brevísima relación de la destrucción de las Indias, de fray Bartolomé de las Casas, desde el punto de vista de la "crueldad". Se centra en la lectura de dos extensos pasajes de la Historia de Sainville y Léonore -integrados, a su vez, a la "novela filosófica" Aline y Valcour-. A partir de la lectura del Suplemento al viaje de Bougainville, de Denis Diderot, y siempre en contraste o relación, aunque distante, con la obra de Las Casas, se describe la visión de lo que el etnólogo Pierre Clastres cifró como el "espíritu de las leyes salvajes”, su anarquía y su crueldad, en la utopía de Zamé, rey de la isla fabulosa de Tamoé, en los mares del sur, y en la aún menos conocida distopía del reino antropófago de Butua, en el golfo de Guinea.
\end{abstract}

Palabras clave: crónicas, Conquista, fray Bartolomé de las Casas, Marqués de Sade, Denis Diderot, Louis Antoine de Bougainville.

Abstract: This article builds on broader research into the Brevisima relación de la destrucción de las Indias, by fray Bartolomé de las Casas, from the point of view of "cruelty." It focuses on the analysis of two long passages from the History of Sainville and Léonore - integrated, in turn, in the "philosophical novel" Aline and Valcour - Reading the Supplement to the journey of Bougainville, by Denis Diderot, continuously in contrast to, or in (distant) relationship with, the work of Las Casas, we see that it describes the vision of what the ethnologist Pierre Clastres calls the "spirit of the wild laws," its anarchy and cruelty, in the utopia of Zamé, king of the fabulous island of Tamoé, in the Southern Seas, and in the less well-known dystopia of the cannibalistic kingdom of Butua, in the Gulf of Guinea.

Key words: chronicles, Conquest, Bro. Bartolomé de las Casas, Marquis de Sade, Denis Diderot, Louis Antoine de Bougainville.

\footnotetext{
* Enrique Flores. Doctor en Letras Hispánicas por El Colegio de México, México. Profesor-investigador en el Instituto de Investigaciones Filológicas de la Universidad Nacional Autónoma de México, México. Temas de especialización: literatura colonial, etnopoéticas. Correo electrónico: flowers@unam.mx. ORCID: https://orcid.org/0000-0002-7940-8142
}

Enviado a dictamen: 25 de septiembre de 2020

Aprobación: 9 de diciembre de 2020 
Estoy solo aquí, estoy en el fin del mundo, ajeno a todas las miradas y sin que pueda ser posible que ninguna criatura llegue hasta mí; nada de frenos, nada de barreras.Las 120 jornadas de Sodoma. Marqués de Sade.

\section{Introducción}

$\square$ espíritu de las leyes salvajes es el título de un libro compilado por Miguel Abensour (2007) que gira en torno al pensamiento político del gran etnólogo anarquista que fue Pierre Clastres, y cuya resonancia puede percibirse en una obra en cierto modo atípica del Marqués de Sade: la Historia de Zamé (fragmento de "Aline y Valcour"). Parte a su vez de la "novela filosófica" Aline y Valcour, la historia del reino de la isla de Tamoé — tan admirada por el escritor guaraní Augusto Roa Bastos, que imagina al Divino Marqués como alter ego de El Supremo-. Es un extenso parlamento que se inscribe, por inusitado que parezca, en el género de las utopías, aunque también se alíe profundamente con las bitácoras ilustradas de viaje y con la primitiva etnología filosófica del enciclopedismo iluminista, como lo prueban la fantasía volteriana evocada igualmente por Roa Bastos, o la distopía sadiana que precede a la Historia de Zamé en la Historia de Sainville y Leonore: la historia del reino de Butua situado en África, muy alejado, por cierto, de aquella isla oscilante entre el Paraguay - "isla rodeada de tierra", como la define Roa Bastos ${ }^{1}{ }^{1}$ y ciertas islas "edénicas" del Pacífico Sur, como Tahití. Distopía antropófaga esta vez, a diferencia o a semejanza de otro gran libro de Pierre Clastres (1986): la Crónica de los indios guayaquis, que no solo describe las condiciones de una sociedad "contra el Estado", sino también de una guerra y una violencia "primitivas".

El Suplemento al viaje de Bougainville, de Diderot (2013), representa indudablemente una mutación en la manera de percibir la alteridad, "lo otro", en la medida en que podía hacerlo un filósofo europeo a finales del siglo XVIII. Hay incluso una dimensión utópica y anárquica en el Suplemento, que captó Sade, aunque llevada a su mayor extremo. Y es que la Historia de Zamé — escrita en la prisión de la Bastilla entre 1785 y 1788, y publicada en 1793-, sin los "excesos" orgiásticos o criminales que caracterizan a la obra sadiana, abre lo imaginario a una multiplicidad de visiones equívocas, desde una perspectiva crítica de la "civilización" hasta cierta apología del "salvajismo" o la "barbarie" — colonialistas y anticolonialistas-.

Tal vez el encuentro imaginado por el novelista paraguayo entre "El Supremo" y el "Divino Marqués", en esa gran novela que disemina aún sus claves históricas y políticas, no se halle fuera de lugar en un texto que intenta articular las conexiones, ajenas al rigor de las comprobaciones históricas pero no por ello menos reales, entre las reflexiones relativas a la crueldad conquistadora y colonizadora, con sus patológicas herencias políticas a lo largo de los siglos, y las escenificaciones exhibidas por Sade y por fray Bartolomé de las Casas en la Brevísima relación de la destrucción de las Indias, en la doble vertiente dialéctica que lleva de la inocencia a la crueldad - la parábola del lobo y las ovejas - y del crimen a la utopía.

Transcribo parte del dictado del "Supremo" y del discurso de Zamé, y enseguida el comentario o la "nota del compilador" — que se confunde con el autor- de Yo el Supremo:

Nada han escrito sobre el castigo que mejor define la esencia justiciera del régimen penal en este país. La condena a remo perpetuo. Cobardía, robo, traición, crímenes capitales son sometidos a ella. No se envía al culpable a la muerte. Simplemente se le aparta de la vida. Cumple su objeto porque aísla al culpable de la sociedad contra la cual delinquió. Nada tiene de opuesto a la naturaleza; lo que hace es devolverlo a ella. La descripción del criminal es enviada a todos los pueblos, villorrios, a los lugares más remotos donde exista el menor rastro humano. Estricta prohibición de recibirlo. Se lo mete engrillado en una canoa en la que se ponen víveres para un mes. Se le indican los lugares donde podrá encontrar más bastimentos mientras pueda seguir bogando. Se le da la orden de alejarse, de no volver a pisar jamás tierra firme. A partir de ese momento, únicamente a él le incumbe su suerte. Libro a la sociedad de su presencia y no tengo que reprocharme su muerte. Todo lo que está 
por debajo de la línea de flotación de esa canoa, no vale la sangre de un ciudadano. Me guardo pues de derramarla. El culpable irá bogando de orilla a orilla, remontando o bajando el ancho río de la Patria, librado a su entera voluntad-libertad. Prefiero corregir y no imponer un castigo que no sea ejemplarizador. Lo primero conserva al hombre y, si él mismo se empeña, lo mejora. Lo segundo lo elimina, sin que el castigo le sirva de escarmiento a él ni a los demás. El amor propio es el sentimiento más vivo y activo del hombre. Culpable o inocente.

Un autor de nuestros días ha tejido una leyenda sobre esta condena del destinado que va bogando sin término y encuentra al fin la tercera orilla del río. Yo mismo, para establecerla aquí, me inspiré en una historia narrada por un libertino en la Bastilla, que solía repetirme un prisionero francés en las siestas del tórrido verano paraguayo. Yo tomo lo bueno donde lo encuentro. A veces, los más depravados libertinos cumplen sin quererlo una función de higiene pública. Este noble degenerado preso en la Bastilla, reflejó en su utopía de la imaginaria isla de Tamoraé la isla revolucionaria del Paraguay, ejemplar realidad que ustedes calumniaron (Roa Bastos, 1974:131-132).

La extensión de la cita es necesaria para la comprensión del pasaje. Y también para la irradiación de perspectivas surgidas del montaje de fragmentos literarios y documentales:

"Tras haber destruido cuidadosamente todo lo que puede conducir al asesinato", prosiguió Zamé; "puedo darle pocos ejemplos de un hecho tan monstruoso en mi isla; el castigo que impongo es sencillo: apartar al culpable de la sociedad, sin que esto suponga contrariar a la naturaleza; envío a todas las ciudades los datos personales del criminal, prohibiendo expresamente que se le reciba; le doy una piragua en la que se colocan víveres para un mes; sólo él va en la embarcación, recibiendo la orden de alejarse y de no desembarcar nunca jamás en la isla, bajo pena de muerte; de él mismo dependerá su suerte; yo libro a mi patria de su presencia, sin que tenga que reprocharme su posible muerte; este es el único crimen que se castiga así; todo lo que está por debajo no vale la sangre de un ciudadano, guardándome mucho de propagarla como compensación; prefiero enmendar antes que castigar; lo primero permite que un hombre siga siendo un hombre y lo mejora; lo segundo lo lleva a la perdición; lo que es una inutilidad; ya le he referido mis métodos, que casi siempre tienen éxito: el amor propio es el sentimiento más activo del hombre; se consigue todo si lo hacemos intervenir (Sade, 2018:154-155)

Este es el fragmento original de la Historia de Zamé, retomado por Roa Bastos en Yo el Supremo. Y por último, la "nota del compilador" que alude, ella sí, a Sade:

Sin duda El Supremo alude a la narración sadiana $\mathrm{La}$ isla de Tamoé, conocida en el Paraguay un siglo antes de ser publicada en la misma Francia y en el resto del mundo, mediante la versión oral del memorioso Charles Andreu-Legard, compañero del marqués en la Bastilla y en la Sección de Picas; después prisionero del Dictador Perpetuo, durante los primeros años de la Dictadura, según consta en los comienzos de estos Apuntes.

La alteración del nombre de la isla imaginaria Tamoé por el de Tamoraé es un error de El Supremo, inconsciente, o quizás deliberado. El vocablo tamoraé significa, en guaraní, aproximadamente: ojalá-así-sea. En sentido figurado: Isla o Tierra de la Promesa (N. del C.) (Roa Bastos, 1974:132).

El conde Louis Antoine de Bougainville publicó su Descripción de unviaje alrededor del mundo, realizado entre 1766 y 1769, en el año de 1771, y Denis Diderot, impresionado por el libro y en especial por las alusiones a las costumbres de los habitantes de la isla de Tahití — su libertad sexual, su régimen de propiedad, su sistema protocomunista de gobierno-, se apresura a redactar y a publicar en 1772 un imaginario Suplemento al viaje de Bougainville, en el que se daría cuenta de noticias no incluidas en la Descripción original. Lo 
imaginario, se diría, invade las fuentes históricas, y así como Sade imagina un ficticio conocimiento del francés en Zamé y sus súbditos de la isla de Tamoé, y Roa Bastos postula una etimología de Tamoé, o Tamoraé, que la aproxima a la noción utópico-mesiánica guaraní de la "tierra sin mal", Diderot imagina un remoto sustrato español en el discurso tal vez más interesante del libro, la "arenga" nativa que ocupa el segundo capítulo - "La despedida de un anciano"cuya complejidad semiótica e intercultural de lengua y de traducción, curiosamente descrita por Diderot, explicaría la supresión de este "fragmento" en la Descripción de Bougainville:

\section{A:Este discurso me parece vehemente, pero a través de un no sé qué abrupto y salvaje, me parece encontrar en él ideas y matices europeos. \\ B: Pensad que se trata de una traducción del otahetia- no al español y del español al francés. Por la noche el anciano se había dirigido a casa de este Orou, a quien interpeló y en cuya choza el uso de la lengua española se había conservado desde tiempos inme- moriales. Orou había escrito la arenga del anciano en español y Bougainville tenía una copia en la mano mientras el otahetiano la pronunciaba. \\ A:Comprendo perfectamente la razón por la que Bougainville suprimió este fragmento (Diderot, 2013:39).}

En los relatos de Sainville y del príncipe Zamé, en la novela de Sade, hay ecos más chovinistas del Suplemento de Diderot. Allí, la lengua preexistente que hace posible que los europeos se comuniquen con la gente de Tamoé es, por supuesto, el francés. Dice Sainville:

Envié al terrateniente en una chalupa para ver si encontraba un atracadero y para que sondease la actitud de los habitantes. Regresó tres horas después con algunos nativos que habían solicitado saludarme, lo que hicieron a la europea. Les hablé una por una en las lenguas de ese continente, pero no me comprendieron en ninguna de ellas. Sin embargo, me di cuenta de que prestaban más atención cuando utilizaba la lengua francesa, y observé que sus oídos estaban habituados a entender su sonido. Fuera como fuese, sus señales eran perfectamente inteligibles y no tenían nada de salvaje (Sade, 2018:50).

A Zamé, hijo de "una mujer de esta tierra" (Sade, 2018:65) y de un oficial francés arribado a la isla en un barco de guerra, durante una expedición por el Pacífico, Sainville lo describe así:

Zamé, tal es el nombre de ese extraño hombre, tendría unos setenta años, aunque apenas aparentaba los cincuenta. Era grande. Su aspecto era apacible. Su porte, noble. Su sonrisa tenía gracia. Era vivo de mirada. Y la frente está cubierta con los más hermosos cabellos blancos. Unía, en fin, a la prudencia de la edad madura toda la majestad de la vejez. Desde el momento en que nos vio, se dio cuenta de que éramos europeos, y sabiendo que el francés es el idioma más usado en ese continente, rápidamente me preguntó en esa lengua cuál era mi nación: "De la que su majestad habla el idioma”, le dije saludándole. "Lo conozco", me respondió Zamé. "Viví tres años en su patria” (Sade, 2018:53).

En efecto, "a finales del reinado de Luis XIV", aquel oficial francés desembarcado en esa isla de Tamoé, "que ningún navegante conocía con anterioridad y que ningún otro ha visto después", atestiguó cómo "la tripulación permaneció en ella más de un mes, abusó del estado de debilidad e inocencia en que encontró a este pueblo infeliz y cometió todo tipo de barbaridades". Perdidamente enamorado de la isleña y "profundamente unido a este pueblo tan bueno e inspirador", el joven marinero se escondió, dejó que sus compatriotas se fuesen y quiso proteger a los isleños de las desgracias que presagiaba el descubrimiento de su país. Indicó a los jefes un punto en la isla donde por desgracia había una mina de oro, y les dijo:

-Esto es lo que enardece la sed de las gentes de mi patria. Este vil metal, cuyo uso ignoran y por el que caminan sin reparar en él, es el objeto más preciado de sus deseos. Regresarán para arrancarlo de las en- 
trañas de la tierra y los someterán, los apresarán y los exterminarán, y, lo que tal vez sea peor, los confinarán, como hacen cada día ellos y sus vecinos, los españoles, en un continente situado a cientos de leguas del suyo cuya ubicación ignoráis, y en el que también abunda este tipo de riqueza (Sade, 2018:65-66).

Notable párrafo que desliza una feroz postura anticolonial, aunque desemboque, al final, como sucede ciertamente con fray Bartolomé de las Casas, en una fantasía mesiánica, salvacionista, cifrada en esta frase: "He pensado que tal vez yo podría salvaguardarles de su voracidad permaneciendo con ustedes" (Sade, 2018:66), o aunque anuncie, como puede vislumbrarse al escuchar el dictado del "Supremo", otras extrañas alianzas del despotismo y la libertad. Así, el joven marinero fascinado por los "salvajes" fortificará la isla, aumentará su aislamiento y a la muerte de su suegro, "uno de los principales mandatarios", por sus conocimientos y por "la superioridad de sus altas miras", será elegido "por unanimidad soberano de la isla", para —en favor de Zamé, educado en las ciencias europeas y destinado a ilustrarse y a viajar por "el mundo entero" - cambiar su constitución y convertir a su gobierno en hereditario (Sade, 2018:67).

Pero volvamos al Suplemento. El tema del diálogo aparece en las primeras páginas: "B: Leo. A: ¿Siempre con ese viaje de Bougainville? A: Siempre" (Diderot, 2013:18). Y reanuda: "A: ¿Y su estilo? B: Natural, apropiado, simple y claro, sobre todo cuando se conoce el lenguaje de los marinos" (2013:19). Curioso, el interlocutor insiste: “A: Hay cosas singulares en este viaje de Bougainville. B: Muchas". El narrador parece quedarse impávido: "A: ¿No asegura que los animales salvajes se acercan al hombre, que los pájaros se posan sobre él cuando ignoran el peligro que entraña esa familiaridad? B: Otros ya lo advirtieron antes que él" (2013:21). Lugares comunes probablemente que no le dicen mucho al filósofo. Pero el interrogador profundiza y el filósofo se plantea otras preguntas más originales, acerca de los isleños: “¿Qué clase de comunicación les unía antaño al resto de su especie? ¿Qué les pudo ocurrir, al multiplicarse sobre un espacio que no tiene más de una legua de diámetro?".
Y aquí entra la "crueldad":

A:Se exterminaban y se devoraban; de ahí quizá una primera época, muy antigua y muy natural, de antropofagia, de origen insular.

B: O la multiplicación se limitó por alguna ley supersticiosa; o el niño era aplastado en el vientre materno por los pies de una sacerdotisa.

A:O el hombre degollado expiraba bajo el cuchillo de un sacerdote; o recurrían a la castración de los machos...

B: A la infibulación de las hembras; de ahí tantas costumbres de una crueldad extraña y necesaria, cuyo origen se perdió en la noche de los tiempos, y somete a tortura a los philosophes (Diderot, 2013:22-23).

"Crueldad extraña y necesaria...”: extraña, y cruel, ironía la que "somete a tortura" a los filósofos. Como estas visiones fantasmales de sacrificio y castración, o de canibalismo — de origen extrañamente "insular" - o esta fobia a la "multiplicación", a la reproducción, tan próxima a Sade y a las "despoblaciones" que abundan en la Destrucción lascasiana. Las frases dedicadas a la expulsión de los jesuitas de su "Imperio Guaranítico", a las tiranías de esos "crueles espartanos de negra sotana" hacia sus "esclavos indios", ¿no hacen resonar en los oídos las "crueldades" de los conquistadores denunciados en la Brevísima, y a la vez, de una manera contradictoria, la defensa - quebrada, desgarrada aquí, como otra "conversión" de las "ovejas" en "lobos"-, la protección de la inocencia por los frailes evangelizadores?

A: ¿No se encontraba en Paraguay en el mismo momento en que fueron expulsados los jesuitas?

B: Sí.

A:¿Qué dice sobre ello?

B: Más o menos lo que podía decir; pero no lo suficiente para que nos enteremos de lo que esos crueles espartanos de negra sotana hacían con sus esclavos indios, como los lacedemonios con los ilotas; los habían condenado a un trabajo incesante; se abrevaban en su sudor; no les daban ningún derecho de propiedad; se les sometía bajo el embrutecimiento 
de la superstición; les exigían veneración profunda; caminaban entre ellos, látigo en mano, y les golpeaban sin distinción de edad ni sexo (Diderot, 2013:23-24).

“iY de los salvajes, qué es lo que piensa?", pregunta el interlocutor. Y el filósofo vuelve a referirse a la "crueldad", sin detenerse ante una analogía con las "bestias feroces":

\section{B: Por lo que parece, deben el carácter cruel que se ha señalado, al enfrentamiento cotidiano que deben mantener para su defensa con las bestias feroces; son inocentes y dulces allí donde nada turba su reposo ni su seguridad. Todas las guerras nacen de la pretensión común a una misma propiedad. \\ A:Y el tigre tiene una pretensión común con el hom- bre salvaje por la posesión de una selva (Diderot, 2013:24-25). ${ }^{2}$}

Aparte de las costumbres sexuales - “el uso común de las mujeres estaba tan bien arraigado en su espíritu que se abalanzó sobre la primera europea que acudió a su encuentro y se dispuso [...] a hacerle la cortesía de Otaheite" (Diderot, 2013:25) —, 3 el Suplemento pone de relieve la "vida salvaje" y su contraste con la "civilización", en detrimento siempre de la "libertad":

B: iLa vida salvaje es tan simple y nuestra sociedad una máquina tan complicada! El otahetiano se halla en los orígenes del mundo y el europeo en su vejez. El intervalo que lo separa de nosotros es más grande que la distancia media entre un niño recién nacido y un hombre decrépito. No entiende nada de nuestras costumbres, de nuestras leyes, en las que no ve más que trabas disfrazadas de mil formas distintas, trabas que no pueden menos que suscitar la indignación y el desprecio en un ser para el que la libertad es el más profundo de los sentimientos (Diderot, 2013:27).

Sade dedicará buena parte del gran parlamento de Zamé a denunciar precisamente las leyes, cuya "espuma" son las criaturas cuando se trata de las leyes de la naturaleza, pero que, en la sociedad humana, son, según Sade, artificios o simulacros contraproducentes que es preciso eliminar. Pero los otahetianos también se preguntan cómo es posible respetar las leyes cuando estas se contradicen entre sí (Diderot, 2013:85), y siempre "con el riesgo de multiplicar a los malvados en lugar de convertirlos en buenos" (2013:86) —como también explicará Zamé-. "El pueblo más salvaje de la tierra", dice Diderot, "el otahetiano, que observa rigurosamente las leyes de la naturaleza [como el pueblo de Tamoé o como los salvajes lascasianos], está más próximo a una mejor legislación que ningún otro pueblo civilizado" (2013:86). "Según sus leyes, nada es erróneo, salvo lo que está mal según su naturaleza” (2013:84). Reina el comunismo, en el ámbito de la producción y en el de la pasión amorosa o el "apetito" sexual, reduciéndose así los "desórdenes" y esbozándose una dulce utopía "familiar" que ignora el tabú del incesto:

B: Los trabajos y las cosechas se realizan en común. El concepto de la palabra propiedad les resulta demasiado limitado. La pasión del amor, reducida a un simple apetito físico, no produce ninguno de esos desórdenes. Toda la isla ofrece la imagen de una única familia en la que cada cabaña representa las diversas estancias de nuestras grandes mansiones (Diderot, 2013:84).

Tal vez la parte más "escandalosa" de la descripción de las costumbres sexuales de Otaheite sea justamente la desaparición, o el desvanecimiento, de la prohibición del incesto. Aquella tiene lugar en el diálogo entre Orou, el nativo otahetiano, y el capellán de a bordo:

Capellán: ¿Un padre puede acostarse con su hija, una madre con su hijo, un hermano con su hermana, un esposo con la mujer de otro?

Orou: ¿Y por qué no?

Capellán: La fornicación aún puede pasar, ipero el incesto!, iel adulterio!

Orou: ¿Qué quieres decir con tus palabras de incesto, fornicación y adulterio?

Capellán: Crímenes, crímenes enormes, por uno de 
los cuales en nuestro país te mandan a la hoguera.

Orou:Que en tu país los manden, o no, a la hoguera, poco importa [...]. Dime lo que tu crimen de incesto tiene en contra de los fines de nuestros actos. Te equivocas, amigo mío, si crees que se ha dicho todo una vez promulgada una ley, una vez inventada una palabra ignominiosa y aplicado un suplicio. Respóndeme entonces: iqué es lo que entiendes por incesto?

Capellán: Pero un incesto...

Orou: ¿Un incesto...? ¿Hace mucho que tu gran artesano sin cabeza y sin manos ni herramienta hizo el mundo?

Capellán: No.

Orou:iE hizo toda especie humana a la vez?

Capellán: No, tan sólo creó un hombre y una mujer. Orou: ¿Y tuvieron hijos?

Capellán: Por descontado.

Orou.Supón que estos primeros padres sólo hubieran tenido hijas, y que su madre hubiera muerto en primer lugar, o que no hubiesen tenido más que varones, y que la mujer hubiera perdido a su esposo.

Capellán: Me pones en un aprieto; sin embargo, por mucho que digas, el incesto es un crimen abominable. Hablemos de otra cosa.

Orou: Di cuanto quieras, pero yo no dejaré de hablar hasta que no me hayas explicado qué es esto del crimen abominable del incesto (Diderot, 2013:71-73).

El capellán termina aceptando que "tal vez el incesto no vaya contra la naturaleza”. Pero, agrega: "ino es suficiente que amenace el orden político?”. ¿Qué sería de la autoridad y el Estado "si una nación compuesta por varios millones de hombres" se agrupara en torno de "una cincuentena de padres de familia"? A lo que Orou responde que "lo peor que podía suceder es que, en lugar de existir una gran sociedad, existiesen cincuenta pequeñas" (Diderot, 2013:73).

Pero el diálogo sobre el incesto prosigue, en una dirección cada vez más práctica:
Capellán: Sin embargo, me parece que incluso aquí un hijo raramente se acuesta con su madre.

Orou:A menos que no sienta por ella un gran respeto y una ternura que le haga olvidar la diferencia de edad y que prefiera a una mujer de cuarenta años a una joven de diecinueve.

Capellán: ¿Y el comercio de los padres con sus hijas? Orou:Apenas resulta más frecuente, a menos que la hija sea fea y poco solicitada. Si su padre la ama, se ocupará de prepararle su dote de hijos [...].

Capellán: En lo referente a las uniones entre hermanos y hermanas, no me cabe duda de que deben de ser muy frecuentes.

Orou:Y muy aprobadas (Diderot, 2013:73-74).

La discusión "filosófica" — o "etnográfica" — de Orou y el capellán se tornará más carnal y pondrá en crisis sus votos sacerdotales, y más precisamente el de castidad, sobre el que también se discute. Antes de que Orou le comunique una experiencia transmitida por su hija: "Pero, monje, mi hija me ha dicho que eres un hombre, y un hombre tan robusto como cualquier otahetiano, y que ella esperaba que tus reiteradas caricias no fueran infructuosas":

El capellán explica que se dedicó el resto de la jornada a recorrer la isla y visitar cabañas, y por la noche, tras la cena, el padre y la madre le suplicaron que se acostase con la segunda de sus hijas; Palli se presentó con el mismo vestido que Thia y él pasó la noche lamentándose: “iPero mi religión!, ipero mi estado!". Y que la tercera noche fue presa de los mismos remordimientos con Asato, la mayor; y que la cuarta, por cortesía, la pasó con la esposa de su anfitrión (Diderot, 2013:81-82).

Rebeldes al tabú del incesto, que no tiene en Otaheite ningún efecto traumático, las "pasiones" no entrañan ninguna dimensión mortífera hasta la irrupción de los colonizadores y la aparición del contagio sexual como arma de destrucción y exterminio. Es el tema de la "arenga" del anciano": fabulosa pieza poética que, a riesgo de 
imitar una retórica o un estilo europeos, como apunta el filósofo, crea una obra de arte verbal inimaginable en su tiempo y solo comparable al elogio que hace Montaigne (1991), casi dos siglos antes, en su ensayo sobre los "caníbales", de la "poesía” o los "cantos" de los salvajes. ${ }^{4} \mathrm{La}$ destrucción de una cultura no tiene que operarse a través solamente de las armas, también la acción erótica de los cuerpos puede producirla, como la "arenga" del anciano - himno, elegía, oración o lamento fúnebre que canta la desaparición de la felicidad en la isla - lo manifiesta tristemente: la entrega de los cuerpos y las almas a los recién llegados, cargada de inocencia y marcada por las "leyes de la hospitalidad", si utilizamos la expresión de Klossowsky, fue correspondida con gestos y acciones asesinos y, más criminalmente todavía, con el contagio de males venéreos, capaz de envenenar desde dentro la inocencia y la libertad otahetianas. Pero, si lo que anuncia ese crimen -cerrándose el telón del espectáculo erótico-utópico y dejando en la oscuridad esas acciones por venir que la despedida del anciano oculta o prefiere mantener en el silencio-; si lo que anuncia ese crimen es otro crimen, el asesinato de sus hijas y mujeres por mano de los propios otahetianos, a causa de esa enfermedad que corrompe los cuerpos del deseo y la semilla de la vida; si eso es verdad, hay que reconocer que otra violencia se vislumbraba ya en la "inocencia" de Otaheite: una violencia contra las mujeres inscrita en el código mismo, en el seno mismo de la libertad otahetiana, y que se confunde con lo que podría describirse, en su sentido "filosófico" profundo, como el "sadismo" de Diderot — su fulgor sadiano-:

B: En el [...] fragmento que acabo de leeros, el capellán señala que el otahetiano no se sonroja por los movimientos involuntarios que se despiertan en él cuando está al lado de su mujer y delante de sus hijas, y que cuando éstas lo advierten tal vez se emocionen pero jamás se sienten incomodadas. En el momento en que la mujer se convirtió en propiedad de los hombres, y que el placer furtivo fue considerado como un hurto, nacieron los términos pudor, contención, decencia, virtudes y vicios imaginarios, en una palabra, barreras entre ambos sexos que les impedían invitarse recíprocamente a transgredir las leyes que se les habían impuesto y que con frecuencia producían el efecto contrario, excitando la imaginación y estimulando el deseo (Diderot, 2013: 90).

En principio, lo que pone en escena y desea el Suplemento es una libertad amorosa de ambos sexos. Una libertad erótica inspirada en el placer de los cuerpos y de los espíritus:

B: Cuando veo árboles plantados en torno a nuestros palacios y un vestido de cuello alto que a la vez muestra y oculta parte de la garganta de una dama, me parece reconocer un regreso hacia la selva y la primitiva llamada a nuestra antigua morada. Un otahetiano nos diría: ipor qué te escondes? ¿De qué te avergüenzas? ¿Haces mal al ceder a los impulsos más augustos de la naturaleza? Hombre, si sabes que places, muéstrate abiertamente; mujer, si este hombre te gusta, recíbelo con la misma franqueza (Diderot, 2013:90-91)

"La naturaleza impúdica, que no atiende a convenciones", añade líneas adelante el filósofo, "empuja indistintamente un sexo hacia el otro" (Diderot, 2013:91). Pero es en ese juego pasional, voluptuoso, de los sexos donde puede vislumbrarse ya un germen, una semilla de violencia, que no deja de existir "entre jóvenes libres y perfectamente inocentes" como los de la isla:

B: Si ellos se esperan, se rehúyen, se persiguen, se evitan, se atacan, se defienden, es debido a que la pasión, desigual en su progreso, no se manifiesta en ellos con igual fuerza; de lo que deducimos que la voluptuosidad se reparte, se consume y se apaga de un lado, cuando apenas comienza a nacer en el otro [...]. El corazón de un hombre no se estremece jamás, sus sentidos le ordenan y él obedece. Los sentidos de la mujer se explican y ella teme escucharlos; es misión del hombre ahuyentar su temor, embriagarla y seducirla [...]. Se ha consagrado la resistencia de la mujer; se ha considerado igno- 
miniosa la violencia del hombre, violencia que en Otaheite no sería más que una injuria ligera, y que en nuestras ciudades se convertiría en un crimen (Diderot, 2013:92-93).

Pero, pregunta el interlocutor, ¿cómo es posible que un acto tan importante, al cual "la naturaleza nos incita con la atracción más poderosa", que "el más grande, el más dulce y el más inocente de los deleites”, se haya convertido en "la fuente más abundante de nuestra depravación y nuestros males”? (Diderot, 2013:93). Según Orou, y su intérprete filósofo en el Suplemento de Diderot, las razones son múltiples y pueden encontrarse en las "instituciones religiosas", con sus absurdos repartos de vicios y virtudes; en los "designios políticos de los soberanos" y en "una extraña contradicción común a todas las sociedades existentes", indisociable de la naturaleza de nuestra sociedad y de esas desigualdades sociales. Pero lo que mejor lo explica son las leyes que "han sometido al matrimonio a "una infinidad de formalidades", los "usos y costumbres" que sobrecargan la unión conyugal, y sobre todo, dice Diderot, "la tiranía del hombre que ha convertido la posesión de una mujer en una propiedad" (Diderot, 2013:93). Y esa posesión y tiranía, borradas por esas raras "leyes de la hospitalidad", no existen entre los "salvajes":

\section{B: El imperio de la naturaleza no puede ser destruido:} por muchas trabas que se le pongan, perdurará. Para servirme de la expresión de Marco Aurelio, escribid cuanto queráis en tablas de bronce que el roce de dos intestinos es un crimen; el corazón del hombre se encogerá ante la amenaza de vuestra inscripción y la violencia de sus inclinaciones; pero ese corazón rebelde no cesará de reclamar y, cien veces en el transcurso de vuestra vida, vuestros caracteres terroríficos desaparecerán ante nuestros ojos. Grabad sobre el mármol: "No comerás ni ixión ni grifo; no conocerás otra mujer que la propia; no serás el marido de tu hermana..." Pero no olvidéis aumentar vuestros castigos en proporción a la extravagancia de vuestras prohibiciones. Os volveréis feroces, pero no lograréis desnaturalizarme (Diderot, 2013:95).
La cercanía con los argumentos de la Historia de Zamé es muy grande. Pero lo que habría que preguntarse en primer sitio, en una indagación originada en la imaginación de la "crueldad" — y la "inocencia" - en la Destrucción lascasiana, es cómo afecta a su denuncia o a su puesta en escena de la "máquina de conquista" la ausencia casi absoluta de elementos sexuales en las crónicas de los conquistadores, lo mismo que en la Brevísima, que suma a la "represión" pulsional general de la escritura conquistadora, los votos de castidad del fraile y el silencio asociado a las pulsiones menos abiertamente destructivas, como son las sexuales, en esas escenificaciones - verbales y escriturales, casi teatrales y cinematográficas- de las conquistas. ¿Qué pasa con la condenación de los "pecados sexuales", como la sodomía o el incesto, el adulterio o la homosexualidad? ¿Cuál es el acontecer libidinal en ese "Paraíso de Mahoma"? ¿Qué vínculos existen entre la "crueldad" conquistadora y la expresión libidinal del deseo? La violencia, la crueldad, la destrucción, la aniquilación y la conquista —-formas todas de la pulsión de muerte - animan esa máquina construida por el fraile dominico en su libro, y alientan irresistiblemente un goce y un deseo irrefrenables. Pero ¿cómo cobra forma en el silencio esa "voluntad de nada"? ¿Qué se agita en las aguas lodosas de las ciénagas de la "voluntad de poder"? ¿Cómo se borran las huellas tras "extirparse" esas otras idolatrías?

Sea lo que fuere, hay una fascinación por el "salvajismo". Al grado de que, como en Sade, cuyo personaje - padre de Zamé, "supremo" dictador de Tamoé- lo consuma, hay un deseo de romper los vínculos y permanecer al margen de la "civilización", un deseo en suma de salvajismo. Aunque involucre, como ha señalado Roger Bartra (1992), a un "salvaje artificial":6

B: ¿Queréis saber la historia abreviada de casi toda nuestra miseria? Hela aquí. Existía un hombre natural, introdujeron dentro de ese hombre a un hombre artificial y en las cavernas se inició una guerra permanente que dura desde entonces. En ocasiones el hombre natural es más fuerte, en otras es abatido por el hombre moral y artificial, y en uno u otro caso el triste monstruo se ve tiranizado, 
atenazado, atormentado, enrodado, gimiendo sin cesar (Diderot, 2013:95).

"No obstante", agrega el filósofo, existen circunstancias extremas que devuelven al hombre su simplicidad primigenia". Y su interlocutor responde razonablemente: "La miseria y la enfermedad, dos grandes exorcistas" (Diderot, 2013:96). Pero la pregunta originaria se va decantando:

A:iEs necesario civilizar al hombre, o abandonarlo a sus instintos? [...].

B: Si os proponéis ser su tirano, civilizadlo. Envenenadle con vuestra mejor moral contraria a la naturaleza; ponedle trabas de todo tipo; impedid sus movimientos con mil obstáculos; cargadle de fantasmas que le aterroricen; eternizad la guerra en la caverna y que el hombre natural sea encadenado para siempre al hombre moral [...]. Desconfiad de quien pretende poner orden. Ordenar es siempre hacerse dueño de otros molestándolos (Diderot, 2013:96-97).

En el fondo de todo este armatoste está la imagen de la anarquía. "Los calabreses", ese pueblo legendario por su insumisión y rebeldía, son según Diderot los únicos civilizados libres. "¿Es que os place la anarquía de Calabria?", le pregunta al filósofo su interlocutor, un ilustrado que conoce la tradición bandolera de esa isla. Y el filósofo apela a la experiencia, y apuesta "a que su barbarie es menos perniciosa que nuestra urbanidad" (Diderot, 2013:97). Una anarquía y una barbarie que emanan de la misma Europa y que se expresan como compulsión del orden. “¿De modo que preferís el estado de naturaleza, bruta y salvaje?”, le pregunta al filósofo su interlocutor. "No osaría pronunciarme", responde el filósofo. Los ciudadanos se desnudan y se van a la selva, pero los selváticos jamás se visten para establecerse en las ciudades (2013:98):

A:¿De modo que preferís el estado de naturaleza, bruta y salvaje?

B: No osaría pronunciarme [...].
A:Deduzco que, de cualquier manera, os inclináis a creer que los hombres, cuanto más civilizados están, son peores y más desgraciados.

B: No he visitado todos los lugares del universo, pero os señalo que sólo encontraréis la condición del hombre feliz en Otaheite, y tan sólo soportable en un rincón de Europa. Ahí los amos, sombríos y celosos de su seguridad, se han ocupado de sumirlo en lo que llamáis embrutecimiento ${ }^{7}$ (Diderot, 2013:98-100).

Gauguin y Tahití, al apuntar del alba. Arte bruto, arte primitivo. "Buen salvaje" y "Edad de Oro": "Paraíso de Mahoma", "Tierra sin Mal". Hoja del díptico lascasiano opuesta a la de la crueldad. Y en Sade y en Diderot, imagen irónica y perversa - suplementaria - que pone en escena a "los amos" y a la autoridad, el "salvajismo" y la anarquía. Utopía sádica o sadiana.

En la primera nota a su poema La Verdad, Sade habla así de las guerras de religión:

Se calcula en más de cincuenta millones el número de muertos en las guerras o matanzas de religión. ¿Acaso una sola de ellas vale la sangre de un pájaro? ¿Y la filosofía no debe armarse toda para aniquilar a un Dios en nombre del cual se inmolan tantos seres que valen más que él? (Sade, 1995:13-15, n. 1). ${ }^{8}$

¿Sade anticolonial? ¿Sade utópico? Es lo que parece desprenderse de la lectura de la Historia de Zamé. Con una extraña peculiaridad - antagónica o anti-nómica, literalmente-: que la utopía sadiana tiene en consecuencia una doble vertiente, la del "salvajismo" y la de la "conquista". Y como en la Brevísima, ambas vertientes se cruzan, se mezclan, se confunden: "utopía” de las leyes salvajes y "anarquía" de los conquistadores. Las reflexiones habituales acerca de la "Edad de Oro" y la pretendida inocencia del "salvaje" rousseauniano - el "buen salvaje" - , aunque presentes sin duda en la Historia de Zamé, no impiden que se vislumbren las figuras del "antropófago" de Butua — el otro país "utópico" descrito 
por Sainville —, o el "caníbal" de Montaigne (1991), tan complejo y polivalente él mismo, con sus rasgos manifiestos de "crueldad"; sin hablar de la figura anárquica y violenta del "conquistador", o la del "tirano", o la del déspota "Supremo"; todas esas reflexiones habituales cesan en la "utopía" sadiana.

Sade comparte con los "salvajes" el momento anárquico - y "utópico"- de lo que se llama la negación. Lo atestigua el otro epígrafe de la Historia de Zamé: "He conocido un pueblo dulce, sensible, virtuoso sin leyes, piadoso sin religión" (Ruiz de Samaniego, 2018:9). Están las pasiones sin ley "donde todo surge y desemboca", esa "suprema soberanía" de la "naturaleza pánica y salvaje que todo lo genera y tritura" como un "vertiginoso principio motor sin el cual nada existiría” (Ruiz de Samaniego, 2018:12). ¿Pasiones salvajes o conquistadoras? ¿Idilio iluminista o invasión? ¿Razón o rebelión? En cualquier caso, desde el punto de vista sadiano, la "voluntad humana" es "un efecto no premeditado de la violencia de las pasiones", "un dominio del inconsciente" (2018:14). En ese sentido, "ino resultaría tiránica incluso la más flexible de las leyes?" Solamente la imaginación expresaría los "movimientos incontrolables del espíritu", "su verdad última y secreta" (2018:15). La imaginación, es decir, como en la Brevísima: el despliegue de las imágenes, de esas representaciones o puestas en escena verbales de la "violencia de las pasiones", en el "dominio del inconsciente". Es la "verdad del desencadenamiento" que el hombre es forzado a contener o a callar, pero que revela los "abismos [...] del delirio o el deseo" (2018:16). Por eso el libertino - como el "conquistador", en la Brevísima - es "el gran personaje de este universo en polución", "el gran erótico" o "el déspota del placer", y el relator que, como Las Casas en su "relación", narra o pone en escena esos excesos es su "teórico", su "archi-retórico" (2018:17).

Rige aquí una ley de las pasiones cuya "vocación destructiva" puede enunciarse así:

No conocemos otra justicia que la de nuestras voluptuosidades; no admitimos otras leyes que las de nuestras pasiones; nuestro único principio es infringir todos los principios de la humanidad; la religión sólo merece desprecio (Ruiz de Samaniego, 2018:20).
"Crimen y crítica" se funden, dice el filósofo, en un solo acto de "aislamiento" y de "separación" que convierte al erotismo en "contra-erotismo", "dispositivo gélido, maquinal, textual”, ajeno a la pornografía y próximo a esas "máquinas de guerra" de la "nomadología" deleuziana (Deleuze y Guattari, 2002). ${ }^{9}$ La isla de Tamoé cumple con esa exigencia —utópica - de "separación”. “Allí [...] reina el principio de máxima autarquía social": "como en la comunidad de los libertinos, aquí los súbditos de Zamé forman una sociedad completa", utópicamente organizada - "con su legislador único y sus ayudantes", con "una economía, una moral, una palabra, un tiempo articulado en horarios, en trabajos, en ocios, fiestas y liturgias"-(Ruiz de Samaniego, 2018:20-21). "La separación de un espacio finito y organizado minuciosamente" produce así un "libre y total desarrollo de la imaginación": "como si se tratase de una calculada representación, de una puestaenescena" (2018:21). Una "particular etnografía": "la fantasía del sistema, del protocolo o el programa como cifra de la felicidad y los placeres", como elemento dominante de su "mundo imaginario". Y una "etnografía" aplicada, utópicamente, al héroe occidental - libertino o "conquistador"-, cuando, como sucede en la Brevísima, lo que se representa histórica e imaginariamente no es sino la "destrucción”, las “conquistas". En "su montaje" radica "su particular Utopía” (2018:21).

"El estado natural del hombre es la vida salvaje", argumenta Zamé, y "las leyes y la religión violentan las costumbres" (Ruiz de Samaniego, 2018:22). Y como en El espíritu de las leyes salvajes (Abensour, 2007), vemos vislumbrarse "la máquina de guerra" nietzscheana que en nuestro tiempo, apunta el filósofo, ha pensado también Deleuze (Deleuze y Guattari, 2002): "quien dicta la ley es quien domina el discurso", de ahí que "la lucha por transformar [como hace Las Casas] o simplemente eliminar las leyes se realice con las mismas armas: la palabra escrita / dicha" - la Brevísima tiene ella misma un origen oral, y fue un arma-. Y Sade, como Las Casas, era "un experto en esta práctica sediciosa" (Ruiz de Samaniego, 2018:23).

Como Annie Le Brun (2008) y Roland Barthes (1997), Ruiz de Samaniego hace tangible la pasión de Sade por el teatro en su visión de la utopía. "La tierra utó- 
pica funciona exactamente igual que el medio teatral", forma textual y "espectacular" con que las narraciones sadianas ponen en escena los cuerpos como "fantasías vistas como desde lejos y sin implicación empírica”, o como "montajes gigantescos organizados para y por un poderoso ojo mental" (Ruiz de Samaniego, 2018:23-24). "Toda individualidad o historicidad", dice el filósofo, "aparece borrada" en las imágenes abstractas, lejanas, de ese "gran teatro del mundo". En Las 120 jornadas de Sodoma o en la Historia de Zamé, Sade opera de la misma forma, insertando a sus personajes en un ambiente teatral, "en universos aislados como islas de Utopía", dentro de "universos construidos por ellos mismos a su medida", en los que, "como sostiene Annie Le Brun, la separación es el signo distintivo y definitorio del sistema sadiano", lo que haría lógico que se desemboque "en el género de la narración utópica”, ubicada forzosamente "en un territorio apartado: en otro lugar" (Ruiz de Samaniego, 2018:24). "El teatro, en fin, como otro modelo de utopía", que no solo le permite expresar "todo un mundo corporal oculto", programar gestos y voces, intercambiar papeles e identidades, "espacializar las ideas", o "exhibir el lenguaje en acción", sino "descargar estas mismas elucubraciones en el espectador", como una forma de materialización u "objetivación del deseo", acercándonos inexorablemente al "fondo pulsional" que nos alienta, a través del espectáculo teatral (2018:26). El teatro sería el conductor de una "exasperación unitiva con las fuerzas mismas de producción del mundo"; de un mundo "físico, carnal: material y dinámico" — como en la Brevísima, una "gran máquina de generación y destrucción" o un "desencadenamiento que provoca la ruina de los objetos o los seres"; "una suerte de infinito turbulento", como el de Henri Michaux (1994), en que asoma "el rostro de la muerte como utopía o desorden último e inalcanzable (Ruiz de Samaniego, 2018:26-27)—.

"Tiene razón Blanchot", señala Ruiz de Samaniego: "Sade, si pudo reconocerse en la Revolución, pudo en la medida en que, como tránsito de una ley a otra, ha representado la posibilidad de realizar un régimen sin ley"; como lapso de anomia, de anarquía, constituyó "el instante supremo y utópico que abre la posibilidad de un régimen sin ley" (Ruiz de Samaniego, 2018:27; Blanchot,
1990). Frente a los “excesos de la Revolución”, Sade es un defensor de la razón: como Zamé, piensa que el "instinto del crimen" es "inexpurgable" y que ningún castigo sería capaz de erradicarlo. La pena de muerte, sobre todo, no solo "injuria a la naturaleza": es "el crimen convertido en ley", o peor aún, es en el fondo "una forma cínica mediante la cual la sociedad sigue cumpliendo su deseo más atávico y oscuro" (Ruiz de Samaniego, 2018:28). "Tal es", dice el ensayista, "el delirio sádico, más que sadiano": una razón "fuera de sí, sacada de quicio", o "eyectada en su noche sideral y originaria", sujeta a "potencias agresivas y tremendamente fogosas, crueles incluso para el propio sujeto de conocimiento", en una "destrucción", "una devastación de tal calibre que implicaba", según Bataille, "la voluntad de aniquilación [...] de sí mismo", una voluntad de auto-aniquilación..$^{10} \mathrm{Y}$ es que, apunta Ruiz de Samaniego, "como ya notara Klossowsky, Sade — como los "conquistadores" de la Brevísima, o como su relator- "sólo se siente vivir en la exasperación": "como si hubiese una violencia del entendimiento mismo que estaría en su origen y que sería el secreto inalterable de su propia producción y proliferación" (Ruiz de Samaniego, 2018:29). "El resorte íntimo y oculto", "la verdad no declarada" se exasperan en esa escena de destrucción, enunciada como aquel "mandato incondicional ético que domina por encima de todo sujeto", la "orden impersonal que no viene de ninguna parte pero que el individuo se autoimpone por encima de sí mismo" - como el "mandato" que se "autoimpone" el padre Las Casas-, bajo la figura de un "superyó sádico" que lo somete al yugo de ese "exceso de razón” (Ruiz de Samaniego, 2018:30-31). ${ }^{11}$

Una parte central de la Historia de Zamé es la dedicada a los sistemas políticos, y la anteceden unas líneas que definen el "deseo errático" del extranjero, invasor o conquistador:

\footnotetext{
El extranjero es infausto por causa incluso de su deseo errático, ingobernable, ruinoso para sí mismo y, por contagio, para los demás. Zamé mismo nos lo avisa: "Sólo temo a un enemigo: al europeo, que es tan inconstante y errático que renuncia a sus alegrías para turbar las de los demás; que piensa que lejos de él hay riquezas más preciosas que las suyas; que no para de desear un
} 
gobierno mejor, puesto que no sabe cómo hacer que el suyo sea más armónico" (Ruiz de Samaniego, 2018:35).

Grave definición, y crítica, de la utopía. Pero que en la Historia de Zamé se articula con la exposición de tres sistemas políticos imaginarios, en el fondo igualmente deleznables: "el despotismo antropofágico de Butua", "el comunismo utópico de Zamé" y "el anarquismo criminal de Brigandos y su banda de gitanos" (Ruiz de Samaniego, 2018:36-37). ${ }^{12}$ Y es que la "monarquía utópica" del mestizo ilustrado que es Zamé - modelo utópico del "doctor Francia" o del "Supremo" en la república del Paraguayes un reino absolutista y patriarcal, colonizado y unipersonal. Rige allí un monarca "ilustrado": "Grande por sus virtudes, respetado por su prudencia, protegido por el corazón del pueblo", escribe Sade, y añade: “Al verle, creí que había sido transportado a los tiempos dichosos de la Edad de Oro" (2018:36) — como en las crónicas de la colonización-. "Porque, a fin de cuentas, esta figura paternal, no originaria de la isla, trata a su pueblo como a una comunidad sencilla e infantil [...], de la que [...] no conviene hacerles salir". O "porque a fin de cuentas el Estado [...] lo es todo en Tamoé", pues como argumenta Zamé: "el Estado es quien alimenta al ciudadano, educa a los niños, lo cuida, lo juzga y lo condena, siendo Yo, [que] quede claro, el primer ciudadano del Estado" (Ruiz de Samaniego, 2018:37). El ensayo extraordinario de Étienne de La Boétie, el amigo de Montaigne muerto prematuramente - el Discurso sobrela servidumbre voluntaria, o el Contra Uno-, sintetiza elocuentemente esas ambivalencias o antinomias políticas, pues, como apunta, discretamente, Ruiz de Samaniego:

Toda la vida colectiva de la comunidad se organiza alrededor y en provecho de un solo y único hombre. No deja de resultar irónico, desde luego, que la ideología aparentemente más benigna consista en una acción política sujeta al puro deseo individual de un sujeto [...]. Resulta sintomático comprobar que, al igual que sucede con la figura del libertino, Zamé, el amo de la isla en realidad, sea el único que habla, quien dispone del lenguaje en su totalidad [...]. En su dominio del lenguaje, Zamé se comporta realmente como un ver- dadero maestro de ceremonias, o mejor, como un director de escena (Ruiz de Samaniego, 2018:38).

"Maestro de ceremonias", "amo", "director de escena": cada uno de esos apelativos podría aplicarse a Las Casas, "quien dispone del lenguaje en su totalidad" y expone, hasta el extremo del delirio, la irrefrenable soledad -y la crueldad - del "deseo errático" del sujeto, invasor o conquistador. Porque esa es la condición del cronista, más allá de su "relación", de la orden o el mandato de su "conversión". Él es el "amo" del discurso: "director de escena" o "maestro de ceremonias" en las escenas sucesivas de la "destrucción", en la "suspensión", en el "éxtasis" o en la búsqueda "exquisita" de nuevas "maneras de crueldad". Como sucede en Sade, "él dirige el discurso, el gesto, los cuerpos, las apariciones, la frase y lo que no hay que decir: el interdicto", o el "silencio", de acuerdo con su "particular economía de las pasiones" (Ruiz de Samaniego, 2018:38). De este modo, "a las diversas modalidades del poder político se incorporan las diversas modalidades de la potencia del deseo", y lo que trabaja ahí, como apunta nuevamente Annie Le Brun, bajo la "exuberancia narrativa", es "un intenso proceso de desideologización" (2018:39). Como en Las Casas, en donde el principio ideológico se destroza a lo largo de la historia, y a quien nada podría exigirle una posición, en virtud del alcance de su visión y de su escritura.

Un episodio mucho menos conocido de la Historia de Sainville y Léonore corresponde a la aventura que ilustra justamente la figura utópica o distópica del "despotismo antropofágico". Al final de esta lectura "proyectiva” de la Brevísima relación de la destrucción de las Indias, sobre la oscuridad de la pantalla de la escritura del Marqués de Sade, sería interesante volver a aquella imagen de la "Edad de Oro" o del "buen salvaje" para vislumbrar el lado oscuro ya no de "las Luces" o del utopismo europeo sino del mundo "primitivo" y del "salvajismo". Lo que Clastres (1986) llamó "el espíritu de las leyes salvajes”, a partir de una profunda observación en su Crónica de los indios guayaquis. En efecto, tras naufragar en las costas 
del golfo de Guinea, antes de su experiencia en la isla de Tamoé, cerca de la isla de Otaití, del Suplemento al viaje de Bougainville, Sainville se descubre perdido "en un país poblado por antropófagos" (Sade, 1975:56), o "en tierras pobladas por devoradores de hombres" (1975:57). Allí, oculto en la copa de un árbol - de una manera que recuerda la escena del Facundo, llamado "El Tigre de los Llanos", en que el gaucho trepa a la cima de un árbol sustrayéndose a la ferocidad de otro tigre americano-, contempla fascinado "un espectáculo tan horroroso" como nunca iba a ver en su vida (1975:58):

Los jagas [o los kongo] que acababa de contemplar regresaban triunfantes de un combate que habían tenido con los salvajes del reino de Butua, que está en sus confines. El destacamento se detuvo bajo el mismo árbol que yo acababa de elegir como refugio; eran aproximadamente unos doscientos y conducían a una veintena de prisioneros, que llevaban maniatados con lianas de los árboles. Al llegar allí, el jefe examinó a los desventurados cautivos e hizo avanzar a seis de ellos, a los que derribó él mismo con su maza, divirtiéndose en golpear a cada uno en una parte diferente y probando su habilidad derribándolos de un solo golpe. A cuatro de ellos los despedazaron y los distribuyeron empapados de sangre entre la tropa; no existe ningún matadero donde un buey sea despedazado con tanta rapidez como lo fueron aquellos desgraciados en manos de sus vencedores. Arrancaron de raíz uno de los árboles vecinos, cortaron sus ramas y con ellas hicieron fuego. Luego, en aquel fuego asaron sobre carbones ardientes las piezas de carne humana que acababan de partir. Apenas vieron la llama, se abalanzaron con una voracidad que me hizo estremecer. Mezclaron aquella comida con frecuentes tragos de una bebida que me pareció muy embriagadora, o al menos así lo creo por la clase de rabia y frenesí a que se entregaron tras la cruel comida. Volvieron a levantar el árbol que habían arrancado, lo clavaron en la arena y ataron a él a uno de aquellos desgraciados vencidos que les quedaban: luego se pusieron a danzar en torno suyo, procurando en cada vuelta coger con destreza, mediante un hierro con el que iban armados, un pe- dazo de carne de ese miserable, al que hicieron morir desgarrándole así, poco a poco. Aquel trozo de carne era zampado crudo tan pronto como era cortado, pero antes de llevarlo a la boca había que empaparse el rostro con la sangre que se desprendía. Era una prueba de triunfo (Sade, 1975:58-59).

"Toda la jornada transcurrió en esas execrables ceremonias", narra Sainville. "Y fue sin duda una de las más crueles que yo haya pasado en mi vida" (Sade, 1975:59). ¿Hay que creerle o no a Sainville o a Sade? La ambivalencia es absoluta, más allá del malditismo o lo carnavalesco, al estilo del Satiricón (Petronius, 1997). Lo prueba la ambigüedad fundamental de la distopía de Butua, que no se muestra como un mundo deseable, sino indeseable, descrito por un renegado portugués — "supersticioso", como la mayoría de portugueses y españoles-, fundado, más allá del horror caníbal, en una forma extrema de despotismo misógino que refuerza, por una parte la imagen terrible y guerrera de la amazona o la mujer armada, y por otra la esclavitud y la humillación más extrema, discursivamente rechazada pero expuesta de la manera más "racional", aunque en el fondo gozosa y "cruel", como se expresa en el relato. ${ }^{13}$ La represión radical, y extrema, de la sexualidad, en esa suerte de clandestinidad "supersticiosa" -inquisitorial, como en los últimos capítulos de la novela de Sade-, profundamente violenta, que domina a las crónicas de la "Conquista", emerge abiertamente aquí como un sistema de dominación, o de agresión, jamás abierto o "descubierto". Un "sistema de la agresión" que extiende sus tentáculos a esas otras fantasmagorías que se expresan en el canibalismo - muy real, por cierto-, la sodomía y la anarquía de esos pueblos que, sin embargo, bajo la pluma de Sade, irán recobrando cada vez sus elementos "despóticos", en detrimento de sus expresiones "primitivas", "salvajes".

Imitando, gesticulando a partir de esa experiencia original, Sainville se colocaría en el sitio del público de un "espectáculo" sacrificial celebrado en una "despótica" familiaridad:

Tal era el dios de aquel país. Sobre las gradas del altar... el más espantoso espectáculo se ofreció enseguida 
a nuestras miradas. El príncipe acababa de hacer un sacrificio humano. El lugar en donde me encontraba era su templo y las víctimas recientemente inmoladas palpitaban aún a los pies del ídolo... Las maceraciones que podían todavía verse en los cuerpos de las desgraciadas hostias... la sangre que corría por todos lados... esas cabezas separadas de sus troncos... terminaron por helar mis sentidos... Temblaba de horror... (Sade, 1975:62).

Será el portugués Sarmiento - "hombre blanco, seco, curtido, de unos sesenta y seis años"- quien le sirva a Sainville de "intérprete" ante los antropófagos (Sade, 1975:62-63). Y no solo de su lengua, sino de sus "costumbres", que obedecen en realidad a una "ley de la Naturaleza":

- Precisamente porque tiene demasiadas [mujeres] está saturado -me respondió el intérprete- iOh, francés! ¿No conoces entonces los efectos de la saciedad? Deprava, corrompe los gustos y los aproxima a la Naturaleza, cuando en realidad parece que los aparta de ella... Cuando el grano germina en la tierra, cuando fertiliza y se reproduce, ino es acaso por un proceso de corrupción? ¿Y no es la corrupción la primera de las leyes generadoras? (Sade, 1975:64).

Es la sodomía - nombre no pronunciado por Sainville ni Sarmiento - la que genera esta digresión naturalista, emanada de un intérprete renegado convertido ahora en "filósofo":

-Si juzgo por tu actitud, hermano, ihe de pensar que los placeres depravados de tu dueño han acabado por ser también los tuyos?

—En muchos casos, sí, amigo mío. Contempla a esos jóvenes negros; son ellos los que, lo mismo que a él, me enseñan a prescindir de las mujeres, y además te respondo que con ellos no me privo de nada. Si no fueras tan escrupuloso, te ofrecería uno... Lo mismo que esto... — dijo mostrándome la desagradable carne que saboreaba (Sade, 1975:71).
Sodomía y canibalismo armonizan sus conjunciones, como en la imaginación de los conquistadores, provocando "corrupción” y “destrucción”, “depravación” y "despoblación”:

- No incluyas en la corrupción moral la costumbre de comer carne humana. Es tan simple alimentarse de un hombre como de un buey. Di, si quieres, que la guerra, causa de la destrucción de la especie, es una calamidad; pero una vez hecha esa destrucción, es absolutamente igual que sean las entrañas de la tierra o del hombre las que sirvan de sepulcro a los elementos desorganizados (Sade, 1975:71).

Naturalización de la sodomía y el canibalismo, y más allá, de la propia "destrucción de la especie", súbditas ambas, junto con una antropofagia generalizada, ${ }^{14} \mathrm{del}$ despotismo, la guerra o la crueldad contra las mujeres. ${ }^{15}$ "Ese sexo", aduce Sarmiento, "es el que cumple en esta comarca las mismas tareas que nuestras bestias de tiro cumplen en Europa". Y añade, no se sabe si sarcásticamente: "Son las mujeres las que siembran, las que labran, las que siegan; cuando llegan a las casas son ellas las que limpian, las que sirven, y para colmo de males son siempre ellas las que son inmoladas a los dioses [...], perpetuamente expuestas a la ferocidad de este pueblo bárbaro" (Sade, 1975:72). A la pregunta escandalizada de Sainville acerca del peligro que unas costumbres tan "cruelmente" odiosas revisten para la "población", o la "despoblación", del reino, el portugués responde: "Por eso está también casi destruida...". Y explica cómo las políticas hacia las mujeres refuerzan esa destrucción, esa "despoblación" autodestructora, tal como la idea de que una mujer es "impura" ocho días antes y ocho después de "ese momento del mes en que la naturaleza la purga", dejando solo ocho días al mes en los que es "digna de ser utilizada"; o la "abstinencia rigurosa" a la que se le condena tras dar a luz, de tres años; o "la ignominia que cae sobre la mujer desde el momento en que está embarazada: es objeto de burlas, se la señala con el dedo; incluso los templos le están vedados" (Sade, 1975:73). ¿Utopía distópica o distopía deseada? "Moti- 
vos de despoblación", en todo caso, que reflejan, como el borgiano "horror de los espejos" - "los espejos tienen algo monstruoso"; "los espejos y la cópula son abominables porque multiplican el número de los hombres", escribe Borges (1997) —, ${ }^{16}$ ese "horror ante la propagación de la propia especie", encarnado en los fantasmas de la sodomía y de la destrucción y el odio a las mujeres, e "impreso en el alma de los súbditos de este imperio":

\section{-Pero si este horror ante lapropagación de la propia especie} se halla impreso en el alma de los súbditos de este imperio, está grabado en cambio de modo muy distinto en el alma del monarca que los gobierna: no sólo sus gustos contrarían a las leyes de la Naturaleza, sino que, además, si él llega a olvidarse con una mujer y llega a hacerla sensible, la pena de muerte es el castigo para el excesivo ardor de esa infortunada, y ella sólo duplica su existencia a condición de perder la suya en seguida; por eso estas mujeres toman todo tipo de precauciones para impedir la propagación o paradestruirla (Sade, 1975:71, 73-74). ${ }^{17}$

Para el psicoanálisis, la fobia es "una imagen para nombrar el horror de un goce". Por esa vía podría descubrirse tal vez el vínculo entre el miedo y el deseo, la fascinación y el horror, la crueldad y el goce, que laten - más allá de Sade y la distópica utopía de Butua-, en la Brevísima relación de la destrucción de las Indias. Pero la "destrucción" no se detiene, no cesa ante el fantasma que convoca. Si es una "ley de la Naturaleza", es asimismo una "ley de los imperios" que los lleva a autodestruirse a través de su propia "corrupción”, y al mismo tiempo los somete a una ley de destrucción universal que consuma la caída de los imperios:

—Esos inconvenientes no influyen para nada en los grandes designios de la Naturaleza. ¿Y qué le importa a sus leyes que un imperio sea más o menos poderoso, que crezca por sus virtudes o se destruya por su corrupción? Dicha vicisitud es una de las primeras leyes de esta mano que nos gobierna; los vicios que la ocasionan son, por tanto, necesarios. La Naturaleza no crea más que para corromper; por tanto, si solamente se corrompe mediante los vicios, he aquí que los vicios son una de sus leyes. Los crímenes de los tiranos de Roma, tan funestos para los particulares, no eran más que los medios de que se servía la Naturaleza para la caída del Imperio. Observa, por tanto, que las convenciones sociales se oponen a las de la Naturaleza. Date cuenta, por tanto, de que lo que el hombre castiga es, en cambio, útil a las leyes del Gran Todo, y que lo que el hombre destruye es esencial para el plan general (Sade, 1975:75).

¿Utopía distópica, sátira de la sociedad cortesana, vindicación del "salvajismo"? La irrisión de la escritura sadiana desborda cualquier ironía, destruye los principios y arrasa con las filosofías al uso. Las "leyes salvajes" irrumpen con crueldad y violencia, confundiéndose pronto con el "despotismo" —el imaginario "despotismo antropofágico"-, y finalmente, en una suerte de "mutación antropológica", retoman el vestuario teatral de los imperios romano, español, portugués, esas "teocracias" conquistadoras. La dialéctica de la destrucción sadiana se vuelve contra sí misma y se convierte en autodestrucción, siempre creadora, semejante al mecanismo de aniquilación —enteramente negativo, de una devastación absoluta - descrito por el fraile dominico en la Brevísima, en sus tratados teológico-políticos y en su testamento, y que, como la antigua profecía de la Crónica del rey don Rodrigo (Corral, 2001) y la "pérdida" o "destrucción" de España, desprende otra profecía visionaria de la "destrucción" del Imperio a través de sus propias armas, aunque por razones contrarias a las esgrimidas por Sade, es decir: ya no como consecuencia de las "tiranías" y las "obras infernales de los cristianos", sino del mecanismo de esa "ley de corrupción-generación" descrita por el feroz Sarmiento en el reino de Butua.

Creo que a causa de esas obras impías, perversas e ignominiosas, perpetradas de una forma tan injusta, tiránica y bárbara, Dios repartirá sobre España su furor y su ira, porque toda España, poco o mucho, ha participado de las sangrientas riquezas usurpadas al precio de tantas ruinas y exterminaciones (Todorov, 1987:2). 
Es cierto que, como confiesa el portugués Sarmiento, en "este infame país en el que tengo la desgracia de verme obligado a vivir" - el reino de Butua, como renegado-, "todos los desórdenes están generalizados y todos quedan sin castigo"; como en la isla de Otaití, no existe el tabú del incesto: "un padre no hace ninguna diferencia entre sus hijas, sus hijos, sus esclavos y sus mujeres: todos sirven indiferentemente a sus orgías lascivas" (Sade, 1975:88-89). Ningún "delirio orgiástico" puede convertirse en crimen, "ninguno de sus actos de tiranía y crueldad, ninguno de sus excesos de libertinaje, ninguna de sus hostilidades - de sus guerras, como en "el espíritu de las leyes salvajes"- es considerada un crimen" (Sade, 1975:108-109). Y sin embargo, las leyes y costumbres de Butua parecen aproximarse más a las de los imperios coloniales que al horizonte anárquico —en el sentido no autoritario, no caótico, de la "anarquía del poder" - propio de las sociedades "salvajes". Aun así, el "despotismo antropofágico" de Butua parece ser solamente, en la argumentación del intérprete, un aparatoso simulacro de las "teocracias" europeas, sujetas a mandatos religiosos y a la "superstición" —idólatras y sacrificadoras-:

-A pesar de la escasa moral de este pueblo, a pesar de los crímenes incesantes a que se entrega, es devoto, crédulo y supersticioso; el peso de la religión en su espíritu es casi tan violento como en España o Portugal.

El gobierno teocrático sigue el esquema del gobierno feudal [...]. El ídolo está en todas partes; es el mismo que vimos en el palacio del rey, quien, por otra parte, es el único que posee el privilegio de tener una capilla particular donde hace sacrificios, con independencia del templo de su capital.

La serpiente, que se adora aquí, es el reptil desde hace más tiempo adorado: tuvo ya templos en Egipto, en Fenicia, en Grecia, y su culto pasó de allí a Asia y a África, donde está muy generalizado (Sade, 1975:93). ${ }^{18}$

Y junto al culto está el sacrificio: el sacrificio humano. Para Sarmiento, la "idea" de que "la inmolación del hombre era el sacrificio más puro que se podía ofrecer a la divinidad", "fue producto del orgullo": creyéndose el ser más perfecto sobre la tierra, "imaginó que nada podía servir mejor para calmar a los dioses y hacerlos propicios que el sacrificio", y más que nada, "el sacrificio de su semejante". Por ello:

se multiplicó tanto esta costumbre, y se puede decir que no ha habido ningún pueblo sobre la tierra que no la haya adoptado: los celtas y los germanos inmolaban viejos y prisioneros de guerra; los fenicios y los cartagineses, los persas y los ilirios sacrificaban a sus propios hijos; los tracios y los egipcios, vírgenes (Sade, 1975:94).

La "confesión" de Sarmiento es un efecto de su existencia y su cuerpo, como sucede con los cuerpos de los "conquistadores" — no en balde Las Casas compuso como un arma de guerra sus Avisos y reglas para los confesores, o Confesionario, un panfleto que lo llevaría a un peligro de muerte- - Y la llamo confesión por el tono tan subjetivo en el que se discurre:

- Lo que en mí llamas depravación no es más que una consecuencia de mi existencia. He encontrado la felicidad en mis sistemas y jamás he tenido remordimientos por ello. Por esa tranquilidad, en la senda del mal, me he convencido de la indiferencia de las acciones humanas. Alumbrando la llama de la filosofía en la ardiente hoguera de las pasiones, he comprendido, bajo su luz, que una de las primeras leyes de la Naturaleza era la de variar continuamente todas sus obras, y que en esta oposición se basaba el equilibrio que mantenía el orden general. iPara qué ser virtuoso, me dije, desde el momento en que el mal sirve tanto como el bien? [...]. ¿Por qué habría de inquietarme entonces? - ¿Pero no existen los hombres que te castigarán por ultrajarles?

—Quien les teme no goza [...]. Quien los desafía los irrita [...]. Mi cabeza sólo se levanta hacia el cielo para esperar el látigo. No controlo el brazo que lo maneja, pero me cabe la gloria de desafiarlo (Sade, 1975:85-86).

Y este es el momento de la rebelión - "quien le teme no goza"-, el momento de la "destrucción creadora”, el 
instante de la creación encarnado en la Destrucción de las Indias, el instante del fin, cuando todo vuelve a repetirse conforme a su mismo e idéntico principio:

-Aunque no hubiera un solo hombre sobre la tierra, todo seguiría siendo como hasta ahora va; gozamos de lo que encontramos, pero nada ha sido creado por nosotros; miserables criaturas somos, sometidas a los mismos accidentes que los demás animales, naciendo como ellos; pero, sin embargo, nos atrevemos a tener orgullo; nos atrevemos a creer que el sol luce y las plantas crecen para el disfrute de nuestra propia especie. iOh, deplorable ceguera!

"Convenzámonos de una vez de que la Naturaleza prescindiría tan bien de nosotros como de las hormigas o de las moscas y que, por tanto, no estamos obligados a servirla multiplicando una especie que le es indiferente y cuya total extinción no alteraría ninguna de sus leyes" (Sade, 1975:98).

\section{Notas}

${ }^{1}$ Sobre Yo el Supremo y Sade, véase "Las culturas condenadas: el mitólogo como compilador" (Flores: 2010).

${ }^{2}$ La oposición o la alternancia de la inocencia y la crueldad - o el salvajismo- hacen recordar el título del primer volumen de la biografía del marqués de Sade escrita por Jean-Jacques Pauvert: Sade: una inocencia salvaje (1740-1777). Como declara el autor, ese título proviene de una bella expresión de Annie le Brun (Pauvert, 1989).

3 "Hacer el amor con cuantas damas se le presentaban", anota el editor. El episodio se refiere a un otahetiano, "Aotourou", transportado por Bougainville a Francia y que "falleció en la travesía de vuelta" a su país (Diderot, 2013:105).

"Ver el ensayo "De los caníbales" (Montaigne, 1991:153-163), y la "Despedida de un anciano" (Diderot, 2013:29-41).

${ }^{5} \mathrm{Si}$ bien se abordan algunos de estos temas, la irrupción de la libido es muy esporádica.

${ }^{6}$ Ver El salvaje en el espejo y El salvaje artificial, reunidos después en un volumen único: El mito del salvaje (Bartra, 1992, 1997, 2011).
${ }^{7}$ Diderot no se pronuncia por el anarquismo, pero apela a la ruptura de los vínculos sociales y de la autoridad.

${ }^{8}$ Alberto Ruiz Samaniego usa esta cita como uno de los epígrafes de su introducción a la Historia de Zamé (Ruiz de Samaniego, 2018:9). En las páginas que siguen, me referiré extensamente a ella, que su autor titula: "Sade: teatro crítico universal".

${ }^{9}$ Sobre las "máquinas de guerra", ver el artículo "La Brevísima: el fantasma y el árbol del crimen" (Flores, en prensa).

10 "Ello implicaba", como explica Ruiz de Samaniego en una nota, "no sólo la destrucción de los objetos y de las personas que entran en escena, sino también del autor y de la propia obra" (2018:29, n. 2). Ver en este sentido, el apartado de La literatura y el mal titulado, precisamente: "La voluntad de destrucción de sí mismo" (Bataille, 1991:152-154).

${ }^{11}$ Ruiz de Samaniego vincula estas reflexiones con el ensayo ya clásico de Jacques Lacan (1984): "Kant con Sade".

${ }^{12}$ En el Suplemento, Diderot se refiere a Calabria, tierra legendaria de briganti o de bandoleros, asociándolos a los "salvajes" otahetianos: "A: ¿Es que os place la anarquía de Calabria? B: Apelo a la experiencia, y apuesto a que su barbarie es menos perniciosa que nuestra urbanidad" (Diderot, 2013:97).

${ }^{13}$ La última parte de la historia de Sainville en Butua describe una escena sádica —o sadiana- en la que, sin confesarlo, el protagonista resulta secretamente vencido por las "verdades" perversas del portugués Sarmiento. Ahí, como apunta con insistencia Annie Le Brun, y como sucede también al término del diálogo del Capellán y Orou en el Suplemento al viaje de Bougainville: "No hay ideas sin cuerpo ni cuerpo sin ideas" (Le Brun, 2008: 232).

${ }^{14}$ Que, sin embargo, no alcanza en Butua a las mujeres: “No, voto a Dios!", clama Sarmiento: "Nosotros no comemos la carne de las mujeres; es fibrosa e insípida y no te la servirán jamás en ninguna parte" (Sade, 1975:70).

${ }^{15}$ Ver las obras fundacionales de Rita Segato: La guerra contra las mujeres y Contrapedagogías de la crueldad (Segato, 2016, 2018).

${ }^{16}$ Ver el poema de Borges "Los espejos", en El Hacedor: "Yo que sentí el horror de los espejos..." (Borges, 1997:24), y el comienzo de "Tlön, Uqbar, Orbis Tertius" —otra 
utopía equívoca-, en Ficciones: "Debo a la conjunción de un espejo y de una enciclopedia el descubrimiento de Uqbar [...]. Bioy Casares había cenado conmigo esa noche [...]. Desde el fondo remoto del corredor, el espejo nos acechaba. Descubrimos (en la alta noche ese descubrimiento es inevitable) que los espejos tienen algo monstruoso. Entonces Bioy Casares recordó que uno de los heresiarcas de Uqbar había declarado que los espejos y la cópula son abominables, porque multiplican el número de los hombres [...]. Al día siguiente, Bioy me llamó desde Buenos Aires. Me dijo que tenía a la vista el artículo sobre Uqbar, en el volumen xLvi de la Enciclopedia. No constaba el nombre del heresiarca, pero sí la noticia de su doctrina, formulada en palabras casi idénticas a las repetidas por él, aunque — tal vez- literariamente inferiores. Él había recordado: 'Copulation and mirrors are abominable. El texto de la Enciclopedia decía: 'Para uno de esos gnósticos, el visible universo era una ilusión o (más precisamente) un sofisma. Los espejos y la paternidad son abominables (mirrors and fatherhood are abominable) porque lo multiplican y lo divulgan"' (Borges, 1980:13-15). En psiquiatría, la eisoptrofobia y la catoptrofobia son trastornos de ansiedad relacionados con el miedo enfermizo e irracional a los espejos o al verse reflejado en un espejo.

${ }^{17}$ El esquivamiento de la palabra sodomía - ese "gusto" que "contraría a la Naturaleza" - se continúa aquí en los eufemismos con que alude al embarazo: "si [...] llega a hacerla sensible"; "ella sólo duplica su existencia".

${ }^{18}$ La ausencia de América en esta suerte de mitopoética sadiana de la serpiente es llamativa, aunque explicable por la escasa información historiográfica y etnográfica de Sade, en lo que se refiere a la existencia tangible de los pueblos amerindios y las colonias españolas. El fantasma de la Inquisición domina la imagen del Imperio, como lo muestra el desenlace de la Historia de Sainville y Léonore, tan semejantes a las novelas románticas de tema "español". Por otra parte, es imposible no subrayar la observación sadiana acerca de la "adoración" de la serpiente en todos esos ámbitos — con la ausencia del "Nuevo Mundo"-, que no puede sino hacernos recordar las investigaciones de Aby Warburg entre los "indios pueblo" (Warburg, 2004).

\section{Referencias}

Abensour, Miguel (comp.) (2007). El espíritu de las leyes salvajes. Pierre Clastres o una nueva antropología política (Carina Battaglia, trad.). Buenos Aires: Ediciones del Sol.

Barthes, Roland (1997). Sade, Loyola, Fourier (Alicia Martorell, trad.). Madrid: Cátedra.

Bartra, Roger (1992). El salvaje artificial. México: Era.

Bartra, Roger (1997). El salvaje en el espejo. México: Era, UNAM.

Bartra, Roger (2011). El mito del salvaje. México: FCE.

Bataille, Georges (1971). La literaturay el mal. Madrid: Taurus.

Blanchot, Maurice (1990). Lautréamont y Sade (Enrique Lombera Pallares, trad.). México: FCE.

Borges, Jorge Luis (1997). El Hacedor. Madrid: Alianza.

Borges, Jorge Luis (1980). Ficciones. Buenos Aires: Alianza.

Clastres, Pierre (1986). Crónica de los indios guayaquis. Lo que saben los aché, cazadores nómadas del Paraguay (Alberto Claveria, trad.). Barcelona: Alta Fulla.

Corral, Pedro de (2001). Crónica del rey don Rodrigo, postrimero rey de los godos. (Crónica sarracina) (James Donald Fogelquist, ed.). Madrid: Castalia.

Deleuze, Gilles y Félix Guattari (2002). "1227: Tratado de nomadología: la máquina de guerra”. En Mil mesetas. Capitalismo y esquizofrenia. Madrid: Pre-Textos, pp. 359-431.

Diderot, Denis (2013). Suplemento al viaje de Bougainville (Jaime Rosal, trad.). Madrid: Sd Edicions.

Flores, Enrique (en prensa). "Las culturas condenadas: el mitólogo como compilador”. En Telar. Argentina.

Flores, Enrique (en prensa). "La Brevísima: el fantasma y el árbol del crimen”. En Interpretatio.

Lacan, Jacques (1984). "Kant con Sade". En Escritos 2. México: Siglo XXI, pp. 744-770.

Las Casas, Bartolomé de (1984). Brevísima relación de la destrucción de las Indias (André Saint-Lu, ed.). Madrid: Cátedra.

Le Brun, Annie (2008). Sade, de pronto un bloque de abismo... (Silvio Mattoni, trad.). Buenos Aires: El Cuenco de Plata.

Michaux, Henri (1994). L'Infini turbulent. Paris: Gallimard. Montaigne, Michel de (1991). Ensayos (Juan G. de Luaces, trad.). México: Porrúa. 
Pauvert, Jean-Jacques (1989). Sade: una inocencia salvaje (1740-1777) (Marco Aurelio Galmarini y Luis Samanillo, trad.). Barcelona: Tusquets.

Petronius (1987). Satiricón (Pedro Rodríguez Santidrián, ed. y trad.). Madrid: Alianza.

Roa Bastos, Augusto (1974). Yo el Supremo. México: Siglo XXI.

Ruiz de Samaniego, Alberto (2018). "Sade: teatro crítico universal". En Donatien Alphonse François de Sade. Historia de Zamé (fragmento de "Aline y Valcour") (Eugenio Castro, trad.). Madrid: Círculo de Bellas Artes.

Sade, Donatien Alphonse François de (1975). Historia de Sainville y Léonore (Lourdes Ortiz, trad.). Madrid: Fundamentos, Espiral.
Sade, Donatien Alphonse François de (1995). La Verdad/ La Verité (Ricardo Zelarayán, trad.). Buenos Aires: Atuel.

Sade, Donatien Alphonse François de (2018). Historia de Zamé (fragmento de "Aline y Valcour") (Eugenio Castro, trad.). Madrid: Círculo de Bellas Artes.

Segato, Rita (2016). La guerra contra las mujeres. Buenos Aires: Prometeo.

Segato, Rita (2018). Contrapedagogías de la crueldad. Buenos Aires: Prometeo.

Todorov, Tzvetan (1987). La conquista de América: la cuestión del otro (Flora Botton Burlá, trad.). México: Siglo XXI.

Warburg, Aby (2004). El ritual de la serpiente (Joaquín Etorena Homaeche, trad.). México: Sexto Piso.

Imagen 1. Sainville en el reino imaginario de Butua

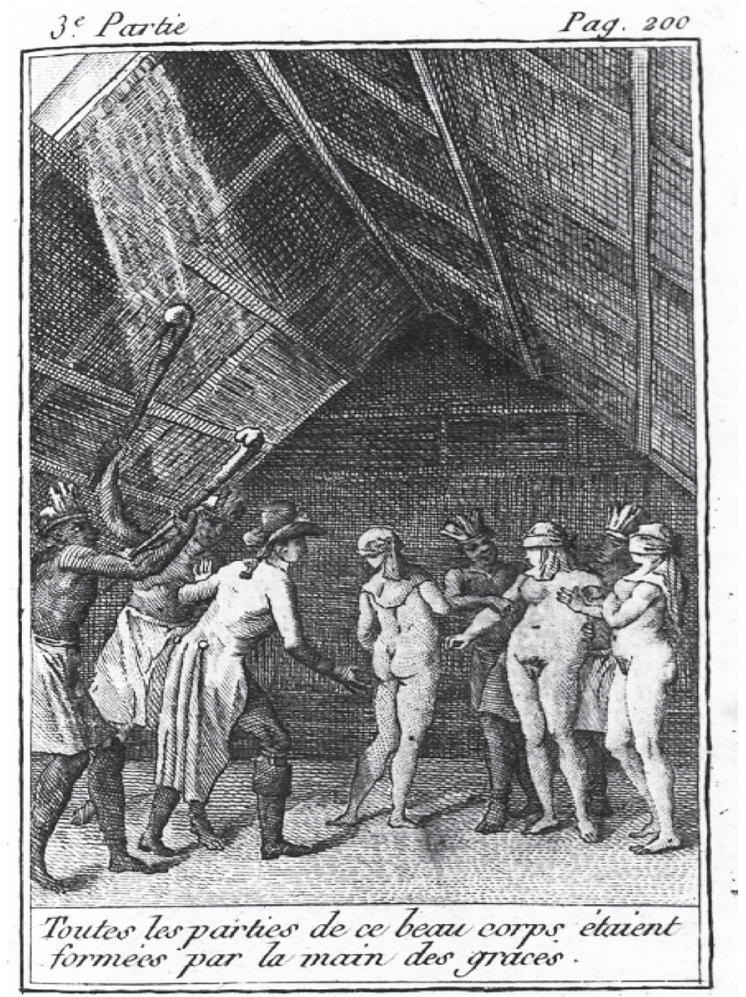

Fuente: Sade (1975). 